\title{
RESEARCH NOTE \\ The in vitro antifungal evaluation of a commercial extract of Chilean propolis against six fungi of agricultural importance
}

\author{
Macarena Curifuta ${ }^{1,2}$, Jorge Vidal ${ }^{2}$, Jaime Sánchez-Venegas ${ }^{2}$, Aliro \\ Contreras $^{1}$, Luis A. Salazar ${ }^{3}$, and Marysol Alvear ${ }^{2,3}$
}

${ }^{1}$ Facultad de Ciencias Agropecuarias y Forestales. ${ }^{2}$ Departamento de Ciencias Químicas y Recursos Naturales, Facultad de Ingeniería, Ciencias y Administración. ${ }^{3}$ Núcleo de Desarrollo Científico-Tecnológico en Biorecursos (BIOREN), Universidad de La Frontera. Av Francisco Salazar 01145. Casilla 54-D, Temuco, Chile.

\begin{abstract}
M. Curifuta, J. Vidal, J. Sánchez, A. Contreras, L.A. Salazar, and M. Alvear. 2012. The in vitro antifungal evaluation of a commercial extract of Chilean propolis against six fungi of agricultural importance. Cien. Inv. Agr. 39(2): 347-359. Propolis has been used for millennia for its antimicrobial and pharmaceutical properties, whereas its use as an agricultural antifungal agent has only recently been assessed. The chemical characteristics of six ethanolic extracts of Chilean propolis (EEP-1 to EEP-6) were evaluated. The total polyphenols ranged between 7.8 and $42.3 \mathrm{mg}$ $\mathrm{mL}^{-1}$ equivalents of a 2:1 pinocembrin: galangin standard, and the total flavonoid contents ranged between 4.0 and $19.7 \mathrm{mg} \mathrm{mL}^{-1}$ equivalents of quercetin. A high-performance liquid chromatographic (HPLC) analysis allowed the identification of caffeic acid, myricetin, quercetin, kaempferol, apigenin, pinocembrin, galangin, caffeic acid phenethyl ester (CAPE) and rutin. The EEP-3 extract was selected for additional studies based on the higher total polyphenols and flavonoids contents (42.3 and $19.7 \mathrm{mg} \mathrm{mL}^{-1}$, respectively). The antifungal effects of four different concentrations $(0.5$, 1.0, 2.5 and $5.0 \%$ ) of EEP-3 on Alternaria alternata, Fusarium sp., Ulocladium sp., Botrytis cinerea, Penicillium expansum and Trichoderma reesei were evaluated in vitro using the agar dilution method. Although significant differences occurred among the extract concentrations, the results indicated that EEP-3 inhibited the mycelial growth of the six fungi evaluated.
\end{abstract}

Key words: Alternaria alternata, antifungal activity, Botrytis cinerea, flavonoids, Fusarium sp., Penicillium expansum, polyphenols, propolis.

\section{Introduction}

In Chile and other countries around the world, phytopathogenic fungi cause serious economic losses in horticultural production systems and post-harvest diseases in fruits and vegetables.

Received May 24, 2011. Accepted January 27, 2012. Corresponding author: malvear@ufro.cl
Although fungicide use is controversial, it is an important component of pest and disease management programs in horticultural production systems. To ensure the sustainability of these systems, a balance needs to be found between controlling the risks of fungal diseases in crops and protecting terrestrial and aquatic ecosystems (Wightwick et al., 2010). During the last few years, considerable efforts have been developed to identify natural products for controlling the diseases of crops, and the use of 
natural compounds, such as the ethanolic extracts of propolis, was suggested as an approach for reducing certain phytopathogenic fungi (Giovanelli, 2008). The first report of the antimicrobial action of propolis against the fungal pathogens of plants was that of Ghaly et al. (1998) who determined the efficacy of an ethanolic extract of propolis against the ascomycete mold fungus Aspergillus flavus with the goal of reducing aflatoxin production.

Currently, fungal diseases cause crops losses approaching $12 \%$ of the world's production (ElShafei et al., 2010), causing a threat to our food supply (Strange and Scott, 2005). Due to the high level of genetic variation, the loss of efficacy of chemical fungicides on fungal pathogens (Latorre et al., 2001) results in a rapid adaptability to these fungicides (Zhao et al., 2009). Therefore, the use of such natural products as propolis for the control of fungal diseases in plants is considered a promising alternative to synthetic fungicides because of their lower negative impact on the environment (Ordóñez et al., 2011).

Propolis (or bee glue) is a natural substance produced by Apis mellifera that is composed of botanical sources, including buds and exudates; it is chewed by the bees, enriching it with salivary secretions, for storage and transportation to the hive where it is then mixed with wax and pollen. The composition of propolis is variable: approximately $50 \%$ resin, $30 \%$ wax, $10 \%$ essential oils, $5 \%$ pollen and 5\% other organic compounds (Russo et al., 2004; Gómez-Caravaca et al., 2006; Falcão et al., 2010). Propolis is thought to be used to seal the beehive (Lotti et al., 2010) to exclude draught and protect it against external invaders. However, its main function is to prevent the decomposition of organic matter (i.e., organisms that have been killed by the bees after invasion) within the hive by inhibiting microbial growth. Therefore, the presence of propolis may provide an environment that is unsuitable for the growth of fungi and other microorganisms, thus maintaining an aseptic hive (Falcão et al., 2010) and creating a protective barrier against enemies (Melliou et al., 2007). Propolis, therefore, is considered to be the most important "chemical weapon" of bees against pathogenic microorganisms (Bankova, 2005a,b). Over 300 compounds have been detected in propolis, and 160 of these have been identified of which $50 \%$ are phenolic compounds, mainly flavonoids (flavones, isoflavones, and flavones), aromatic acids and esters (caffeic acid, cinnamic and others), aromatic aldehydes (vanillin and isovanillin), coumarins and phenolic triglycerides. In addition, other groups of compounds and minerals are of fundamental importance for the biological activity of propolis, including provitamin A, certain B vitamins, lactones, polysaccharides, amino acids and other substances not yet identified (Quiroga et al., 2006; Hroboňová et al., 2008; Peña, 2008; Kalogeropoulos et al., 2009; Falcão et al., 2010). The propolis produced by bees is generally purified by extraction with different solvents to remove the wax and organic waste and to preserve the polyphenol fraction, which contains most of the bioactive components of propolis (Gómez-Caravaca et al., 2006; Kalogeropoulos et al., 2009).

Numerous studies have demonstrated the versatile pharmacological activities of propolis, including antibacterial, antifungal, antiviral, antiinflammatory, hepatoprotective, antioxidant, and antitumor properties (Hegazi and Abd El Hady, 2002; Tolosa and Cañizares, 2002; Castagna et al., 2004; Garedew et al., 2004; Popova et al., 2005; Quintero-Mora et al., 2008; Popova et al., 2009; Herrera et al., 2010; Saavedra et al., 2011). The control of phytopathogenic fungi by propolis has been proposed by Hegazi and Abd El Hady (2002) who evaluated the use of Egyptian propolis to control nine postharvest fungi and reported successful inhibition of the fungi, with minimum inhibitory concentration values ranging between 1.2-3.6 $\mathrm{mg} \mathrm{mL}^{-1}$. In other countries, samples of the local propolis have been evaluated by Özcan et al. (2004), Quiroga et al. (2006), Giovanelli (2008), Meneses et al. (2009), and Özdemir et al. (2010) who obtained interesting results against phytopathogenic fungi. However, the development of a propolis extract for use as an agricultural fungicide has not been given much 
attention (Hegazy and Abd El Hady, 2002; Quiroga et al., 2006) in Chile, and data regarding its action against important economical agricultural fungi are limited.

The main goals of this study were a) to determine the chemical characteristics of the six commercial ethanolic extracts of Chilean propolis and b) to evaluate the in vitro antifungal activity of one of these extracts (EEP-3, with higher contents of total polyphenols and flavonoids than the others) in the control of pathogenic fungi in plants $(A$. alternata, Fusarium sp., and Ulocladium sp.), the control of postharvest pathogenic fungi $(B$. cinerea and $P$. expansum). The fungus $T$. reesei was used as a biological control.

\section{Materials and methods}

\section{Commercial propolis extracts}

Six commercial ethanolic extracts of propolis (EEP-1, EEP-2, EEP-3, EEP-4, EEP-5 and EEP-6) were purchased from stores of natural products in Temuco, Chile.

\section{Microorganisms}

The fungal strains used in this study belong to the collection of the Laboratorio de Bioquímica y Biología Molecular de Suelo, Universidad de La Frontera, Temuco, Chile. The fungi tested are of agricultural interest and included Alternaria alternata, Fusarium sp., Ulocladium sp., Botrytis cinerea, Penicillium expansum and Trichoderma reesei. The fungi were morphologically and molecularly characterized.

\section{Identification of fungi by PCR}

The genomic DNA of the fungal isolates was obtained from fresh mycelial cultures. The samples were frozen in liquid nitrogen, ground to a powder using a mortar and pestle and resuspended in TE buffer (10 mMTris/Cl pH 8.0, 1 mM EDTA), with an equal volume of lysis buffer was added ( $2 \%$ $\mathrm{SDS}, 10 \mathrm{mM}$ Tris/Cl, and $1 \mathrm{mM}$ EDTA, $\mathrm{pH}$ 7.0). After incubation on ice for $15 \mathrm{~min}$, the mixture was centrifuged at $3,000 \mathrm{x}$ g for $10 \mathrm{~min}$, and the supernatant was subjected to phenol/chloroform extraction, followed by ethanol precipitation (Sambrook and Russel, 2001). The resulting pellet was resuspended in TE buffer containing 100 $\mu \mathrm{g} \mathrm{mL}^{-1}$ RNaseA (Fermentas ${ }^{\circledR}$ ) and incubated at $37^{\circ} \mathrm{C}$ for $30 \mathrm{~min}$. The suspension was then subjected to phenol/chloroform extraction and ethanol precipitation; the genomic DNA was dissolved in deionized and nuclease-free water. The DNA samples were subjected to PCR using the technique developed by Saiki et al. (1988). The primers used were forward, ITS1 5'-TCCGTAGGTGAACCTGCGG-3', and reverse, ITS4 5'-TCCTCCGCTTATTGATATGC-3', as described by White et al. (1990) and synthesized by Invitrogen, USA. The primers were used to amplify a fragment of rDNA that includes the ribosomal RNA gene (partial sequence), internal transcribed spacer (ITS) 1, the 5.8S ribosomal RNA gene, ITS 2 (complete sequence), and the $28 \mathrm{~S}$ ribosomal RNA gene (partial sequence). The PCR amplifications were performed in a total volume of $50 \mu \mathrm{L}$, with $15 \mathrm{ng}$ template DNA, $20 \mu \mathrm{M}$ each primer, $25 \mu \mathrm{M}$ each dNTP, 2.0 U Taq DNA polymerase (recombinant) and $10 \times$ Taq Buffer $(100 \mathrm{mM}$ Tris/ $\mathrm{Cl}$ [pH 8.8 at 25 ${ }^{\circ} \mathrm{C}$ ], $500 \mathrm{mM} \mathrm{KCl}$, and $0.8 \% \mathrm{v} / \mathrm{v}$ Nonidet-P40 [Fermentas $\left.{ }^{\circledR}\right]$ ). These reactions were subjected to an initial denaturation of $5 \mathrm{~min}$ at $95^{\circ} \mathrm{C}$, followed by 30 cycles of $1 \mathrm{~min}$ at $94^{\circ} \mathrm{C}, 1 \mathrm{~min}$ at $55^{\circ} \mathrm{C}$, and 2 min at $72{ }^{\circ} \mathrm{C}$, with a final extension of 5 min at $72{ }^{\circ} \mathrm{C}$ using a Labnet MultiGene ${ }^{\mathrm{TM}}$ 96-well Gradient Thermal Cycler. Aliquots (2 $\mu \mathrm{L}$ ) were analyzed by electrophoresis through a $1.2 \%(\mathrm{w} / \mathrm{v})$ agarose gel in $1 \times$ TAE buffer $(40$ $\mathrm{mM}$ Tris, $20 \mathrm{mM}$ acetic acid, and $1 \mathrm{mM}$ EDTA, $\mathrm{pH} 8.0$ ), staining with ethidium bromide and imaging using a transilluminator. The molecular size marker was the GeneRuler ${ }^{\mathrm{TM}} 100$ bp Plus DNA Ladder (Fermentas $\left.{ }^{\circledR}\right)$. 
The fragments of the ribosomal DNA region, including the ITS1 and ITS2 spacers and 5.8S (complete sequence), SSU and LSU (partial sequence) genes were sequenced in both directions using an automated DNA sequencing system (ABI, Model 3730XL Genetic Analyser, by Macrogen, Korea). The sequences were compared using the Basic Local Alignment Search Tool (BLAST) database.

\section{Determination of total polyphenols}

The Folin-Ciocalteu method was used to determine the total polyphenol content of the six extracts evaluated (Singleton et al., 1999). Briefly, each extract was diluted 1:10 in 70\% ethanol and then 1:10 in distilled water. Subsequently, $40 \mu \mathrm{L}$ of this dilution was mixed with $560 \mu \mathrm{L}$ distilled water, $100 \mu \mathrm{L}$ of the Folin-Ciocalteu reagent (Merck, Germany) and $300 \mu \mathrm{L}$ of $7.5 \%$ sodium carbonate $(\mathrm{w} / \mathrm{v})$. The absorbance was measured at $760 \mathrm{~nm}$ after $2 \mathrm{~h}$ of incubation at room temperature. The concentrations were calculated from a calibration curve and were expressed in $\mathrm{mg} \mathrm{mL}^{-1}$ equivalents of the mixture of pinocembrin:galangin standards in a 2:1 ratio (Popova et al., 2007). All of the measurements were performed in triplicate.

\section{Total flavonoids}

The total flavonoid content was determined according to the aluminum chloride colorimetric method (Salamanca et al., 2007). Briefly, each EEP was diluted 1:25 in 70\% ethanol, and 0.5 $\mathrm{mL}$ of the sample was mixed with $0.1 \mathrm{~mL} 1 \mathrm{M}$

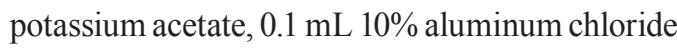
and $0.3 \mathrm{~mL}$ distilled water. After incubation at room temperature for $30 \mathrm{~min}$, the absorbance of the reaction mixture was measured at $415 \mathrm{~nm}$ using a spectrophotometer (Jenway 6320D) with a 70\% ethanol blank. Quercetin was chosen as the standard. The concentrations were calculated from a calibration curve and expressed in $\mathrm{mg}$ quercetin equivalents $\mathrm{mL}^{-1}$.

\section{Chromatographic analysis}

High-performance liquid chromatography (HPLC) was performed using an HPLC system (MerckHitachi model L-4200) equipped with a pump (model L-6200), a UV-visible detector and a Sphere Column Heater (Phenomenex Terma model TS-130). The separation was performed using an RP-18 column $(12.5 \times 0.4 \mathrm{~cm}$, particle size of 5 $\mu \mathrm{m})$ (Merck, Germany) at $25{ }^{\circ} \mathrm{C}$ with a mixture of $5 \%$ formic acid in water (A) and methanol (B) as the mobile phases. The separation of the compounds was performed using an isocratic 0-10 min run with the mixture $70 \% \mathrm{~A}$ and $30 \% \mathrm{~B}$, followed by a gradient up to $100 \%$ B for $70 \mathrm{~min}$. The compounds were detected at $290 \mathrm{~nm}$, with a 0.001 sensitivity; the injection volume was 10 $\mu \mathrm{L}$. The identification of the phenolic compounds was performed using the following standards: myricetin, kaempferol, quercetin, caffeic acid, galangin, pinocembrin, apigenin, caffeic acid phenethyl ester (CAPE) and rutin (Sigma, USA).

\section{Antifungal activity of propolis}

The antifungal potential of propolis was evaluated using the agar dilution method according to the procedure described by Quintero-Mora et al. (2008) and Garedew et al. (2004), with some modifications. The medium was potatodextrose- agar (PDA) sterilized at a temperature of $55^{\circ} \mathrm{C}$, and four culture media were prepared with the propolis selected extract, obtaining concentrations of $0.5,1.0,2.5$ and $5 \%(\mathrm{v} / \mathrm{v})$, according to the volume of medium used, and a control medium without propolis. The mixture was homogenized and poured into sterile Petri dishes (5.2 cm in diameter). As controls, two synthetic fungicides were used: benzimidazole for B. cinerea, Fusarium sp., T. reesei, P. expansum and Ulocladium sp. and dicarboximide for $A$. alternata. The control treatment contained only the PDA culture medium. Fungal plugs ( $5 \mathrm{~mm}$ in diameter) obtained from the actively growing 
margin of five-day-old cultures of each species were obtained and placed at the center of Petri dishes with the PDA media containing the various concentrations of the extracts. The cultures were incubated at $28 \pm 2{ }^{\circ} \mathrm{C}$, and the radial growth of the mycelia were measured daily for 6 days for B. cinerea, 13 days for $A$. alternata and 18 days for Fusarium sp., T. reesei, P. expansum and Ulocladium sp. B. cinerea presented a rapid radial growth of the mycelia and reached the edge of the plates after six days. The percentage of inhibition was calculated on the basis of the growth in the control plates, as follows:

Percentage of mycelial growth inhibition= mycelial growth in control - mycelial growth in propolis mycelial growth in control

The antifungal effect was measured using a random design with three replications.

\section{Determination of the median and ninety effective concentrations}

Little and Hill (1976) have proposed a method for determining the median effective concentration $\left(\mathrm{EC}_{50}\right)$ and ninety effective concentration $\left(\mathrm{EC}_{90}\right)$, defined as the inhibition of 50 and $90 \%$, respectively, of the mycelial growth. For this analysis, it was necessary to transform the concentration of propolis to the natural logarithm, and the percentage of inhibition of the fungi were transformed angularly.

\section{Statistical analysis}

The results were analyzed using an Analysis of Variance (One-Way ANOVA), and the comparisons between the means were performed using the multiple comparison test of Tukey, with a significance level of $5 \%(\mathrm{P} \leq 0.05)$. The statistical program demo SPSS 11 was used.

\section{Results}

Determination of total polyphenols and flavonoids

There was a clear difference in the concentrations of the total polyphenols and flavonoids between the six extracts evaluated (Table 1).

Table 1. Total polyphenols and flavonoids present in six commercial ethanolic extracts of Chilean propolis.

\begin{tabular}{ccc}
\hline $\begin{array}{c}\text { Commercial } \\
\text { ethanolic extract of } \\
\text { propolis (EEP) }\end{array}$ & $\begin{array}{c}\text { Total } \\
\text { Polyphenols, } \\
\mathrm{mg} \mathrm{mL}^{-1}\end{array}$ & $\begin{array}{c}\text { Total } \\
\text { Flavonoids, } \\
\mathrm{mg} \mathrm{mL}^{-1}\end{array}$ \\
\hline EEP-1 & $8.23 \mathrm{a}^{1}$ & $4.83 \mathrm{a}^{1}$ \\
EEP-2 & $17.33 \mathrm{c}$ & $8.83 \mathrm{~b}$ \\
EEP-3 & $42.30 \mathrm{~d}$ & $19.70 \mathrm{~d}$ \\
EEP-4 & $18.37 \mathrm{c}$ & $10.53 \mathrm{c}$ \\
EEP-5 & $14.27 \mathrm{~b}$ & $11.00 \mathrm{c}$ \\
EEP-6 & $7.77 \mathrm{a}$ & $3.97 \mathrm{a}$ \\
\hline
\end{tabular}

${ }^{1}$ Lowercase letters indicate significant differences $(\mathrm{P} \leq 0.05)$ between the total polyphenols and total flavonoids.

EEP-3 demonstrated the highest concentration: $42.3 \mathrm{mg} \mathrm{mL}^{-1} 2: 1$ pinocembrin: galangin equivalents for the total polyphenols and $19.7 \mathrm{mg} \mathrm{mL}^{-1}$ quercetin equivalents for the total flavonoids. The EEP-1 and EEP-6 extracts exhibited the lowest contents, with no significant differences $(\mathrm{P}>0.05)$ between them (Table 1).

\section{Chromatographic analysis}

The chromatographic analysis detected at least 35 compounds in the six EEPs studied, with the identification and quantification of caffeic acid, myricetin, quercetin, kaempferol, apigenin, pinocembrin, galangin, CAPE and rutin (Figure 1, Table 2). The EEP-3 extract has a higher content of kaempferol, galangin and pinocembrin compared to the other extracts (Table 2). 
Table 2. Selected flavonoids of six commercial ethanolic extracts of Chilean propolis $\left(\mathrm{mg} \mathrm{mL}^{-1}\right)$.

\begin{tabular}{cccccccccc}
\hline EEP & Caffeic acid & Myricetin & Quercetin & Kaempferol & Apigenin & Pinocembrin & Galangin & CAPE & Rutin \\
\hline EEP-1 & $0.013 \pm 0.0006$ & 0.00 & 0.00 & $0.15 \pm 0.004$ & $0.01 \pm 0.0002$ & $0.01 \pm 0.0001$ & $0.07 \pm 0.003$ & 0.00 & 0.00 \\
EEP-2 & 0.00 & 0.00 & $0.07 \pm 0.003$ & $0.16 \pm 0.003$ & $0.02 \pm 0.0002$ & $0.01 \pm 0.0001$ & $0.07 \pm 0.002$ & $0.05 \pm 0.0002$ & 0.00 \\
EEP-3 & $0.029 \pm 0.0008$ & $0.04 \pm 0.0003$ & $0.08 \pm 0.002$ & $0.64 \pm 0.001$ & $0.04 \pm 0.0004$ & $0.06 \pm 0.0003$ & $0.11 \pm 0.004$ & $0.10 \pm 0.0006$ & $0.02 \pm 0.0008$ \\
EEP-4 & 0.00 & $0.01 \pm 0.0001$ & $0.07 \pm 0.002$ & $0.15 \pm 0.002$ & $0.01 \pm 0.0001$ & $0.01 \pm 0.0001$ & $0.07 \pm 0.002$ & $0.05 \pm 0.0002$ & 0.00 \\
EEP-5 & $0.015 \pm 0.0005$ & 0.00 & $0.07 \pm 0.003$ & 0.00 & $0.01 \pm 0.0001$ & $0.01 \pm 0.0001$ & $0.07 \pm 0.003$ & $0.05 \pm 0.0003$ & $0.02 \pm 0.0009$ \\
EEP-6 & 0.00 & $0.01 \pm 0.0001$ & $0.07 \pm 0.003$ & 0.00 & 0.00 & $0.01 \pm 0.0001$ & $0.07 \pm 0.003$ & 0.00 & 0.00 \\
\hline
\end{tabular}

CAPE: Caffeic acid phenethyl ester.

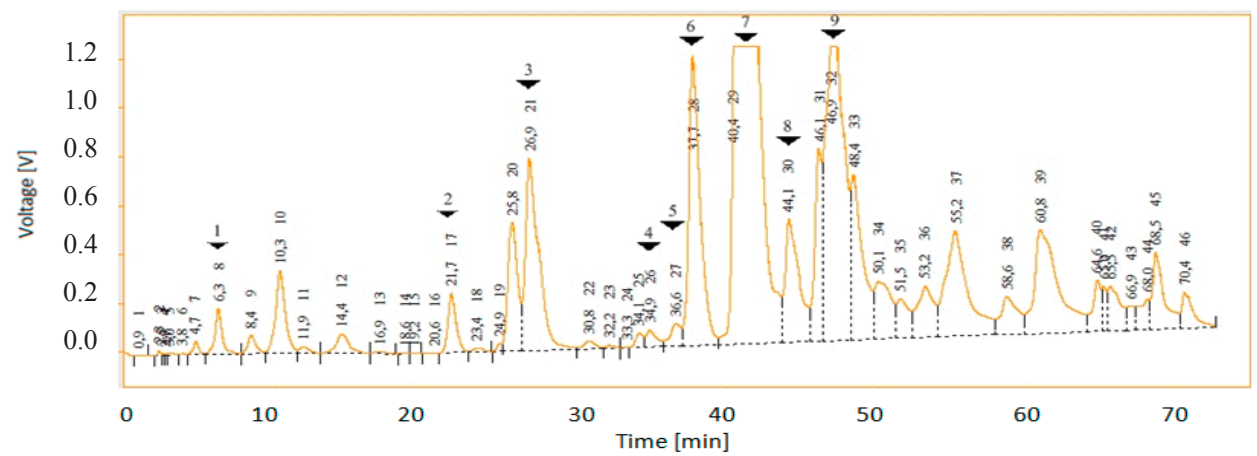

Figure 1. Chromatographic pattern of commercial extract EEP-3. Wavelength: $290 \mathrm{~nm}$. Injection volume: 10 $\mu \mathrm{L}$. Identified compounds: 1, caffeic acid; 2, myricetin; 3, quercetin 4, kaempferol; 5, apigenin; 6, rutin; 7, pinocembrin; 8, galangin; 9, caffeic acid phenethyl ester (CAPE).

\section{Fungal identification}

The morphological analysis of the fungal collections revealed that the genera correspond to Trichoderma, Botrytis, Alternaria, Fusarium, Ulocladium and Penicillium. The PCR identification of the six fungi is shown in Figure 2.

The nucleotide sequence of the ITS regions containing the $5.8 \mathrm{~S}$ ribosomal gene were obtained from isolates of these six fungi, and the sequences were compared using BLAST. Test strains obtained from the culture collections were also molecularly characterized, and their identities as B. cinerea, A. alternata, Fusarium sp., Ulocladium sp. and Trichoderma reesei were confirmed.
The GenBank accession number of the reference sequence is FJ004274 Penicillium expansum.

\section{Antifungal activity}

Considering its high concentration of total polyphenols and flavonoids (Table 1 and Table 2), EEP-3 was selected for further experiments.

The six assessed fungi were sensitive to the high concentration of EEP-3 (Figures 3 and 4).

The efficacy of the treatment with EEP-3 decreased over time. In the first week, no statistically significant differences $(P>0.05)$ between 


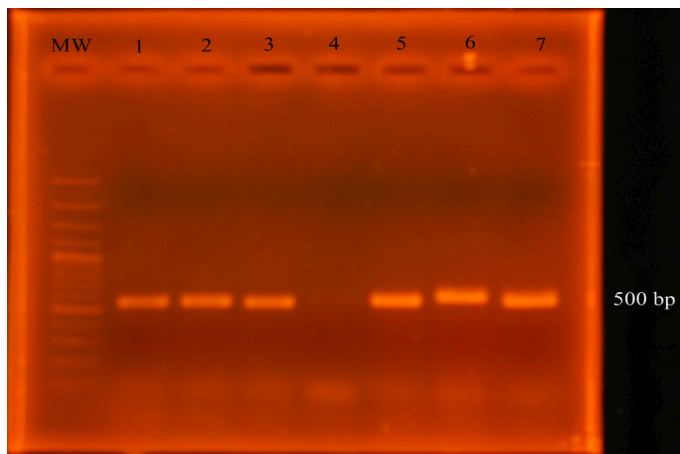

Figure 2. PCR products of the six fungi used for identification. Agarose gel (2\%) stained with ethidium bromide. MW, molecular weight marker; lane 1, Penicillium expansum; lane 2, Botrytis cinerea; lane 3, Alternaria alternata; lane 4, negative control; lane 5, Fusarium sp.; lane 6, Ulocladium sp. and lane 7, Trichoderma reesei.

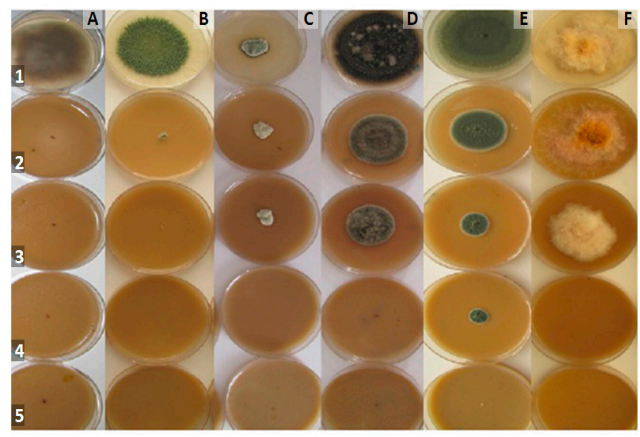

Figure 3. Evaluation of the antifungal activity when the control treatment reached its maximum growth. The letters indicate the fungus used in experiment, and the numbers correspond to the concentrations of the propolis extract added to the culture medium. Fungi: A, Ulocladium sp.; B, Trichoderma reesei; C, Penicillium expansum; D, Alternaria alternata; E, Botrytis cinerea; F, Fusarium sp. EEP-3 extract: 1 , medium alone; $2,0.5 \% ; 3,1.0 \% ; 4,2.5 \% ; 5,5 \%$.

Table 3. The effective concentration (EC) for a 50 and 90 response for the fungi tested (\%).

\begin{tabular}{lccccccc}
\hline & $\begin{array}{c}\text { Alternaria } \\
\text { alternata }\end{array}$ & Fusarium sp. & Ulocladium sp. & $\begin{array}{c}\text { Botrytis } \\
\text { cinerea }\end{array}$ & $\begin{array}{c}\text { Penicillium } \\
\text { expansum }\end{array}$ & $\begin{array}{c}\text { Trichoderma } \\
\text { reesei }\end{array}$ & Average \\
\hline $\mathrm{EC}_{50}$ & 0.53 & 1.23 & 0.001 & 0.48 & 0.99 & 0.01 & 0.54 \\
$\mathrm{EC}_{90}$ & 1.73 & 2.35 & 0.001 & 2.35 & 2.70 & 0.31 & 1.57 \\
\hline
\end{tabular}

the treatments of $0.5 \%$ and $1 \%$ EEP- 3 versus the chemical treatment; this trend was also observed in the second week, with the $2.5 \%$ propolis treatment behaving the same way in the third week. The sensitivity of the six fungi to EEP-3 was demonstrated in this study (Figure 4), decreasing over $60 \%$ of the mycelial growth at the lowest concentration studied and nearly $100 \%$ growth inhibition at the highest concentration used $(0.5$ and $5 \%$, respectively).

\section{Determination of the $E C_{50}$ and $E C_{90}$}

The $\mathrm{EC}_{50}$ and $\mathrm{EC}_{90}$ values of the six fungi evaluated are shown in Table 3. The lowest concentrations of EEP-3 that inhibited approximately $50 \%$ of the mycelial growth of Ulocladium sp. and T. reesei were 0.001 and $0.01 \%$, respectively. The lowest concentrations inhibiting approximately $90 \%$ of the mycelial growth $(0.001 \%-0.31 \%)$ were found for the same fungi.

\section{Discussion}

The total polyphenol and flavonoid concentrations are similar to those reported by Vidal et al. (2009) and Herrera et al. (2010) who also evaluated Chilean commercial ethanol extracts of propolis and were similar to those reported in samples of Argentine (Bedascarrasbure et al., 2004, 2006; Chaillou and Nazareno, 2009) and Brazilian propolis (Castro et al., 2007).

The levels of total polyphenols and flavonoids account for the variability in the chemical composition of the commercial extracts of propolis and are attributable to both endogenous and exogenous factors (Table 1). The observed variability can be explained by the EEPs of a homemade product for which there is not requirement to declare the extraction process. In addition, the composition of propolis is influenced by the flora surrounding the apiary (Chaillou and Nazareno, 2009; Agüero et al., 2010), the 


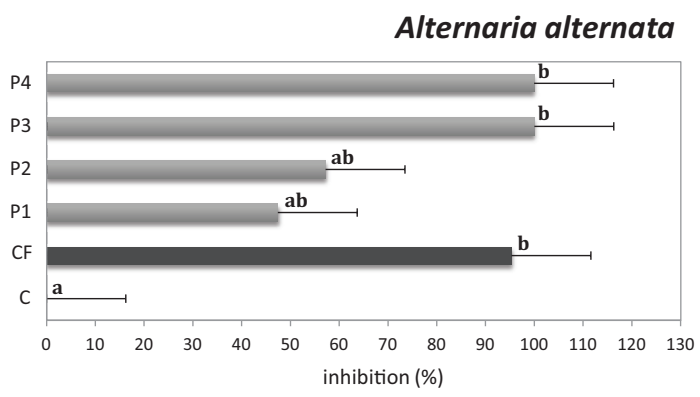

Fusarium sp.

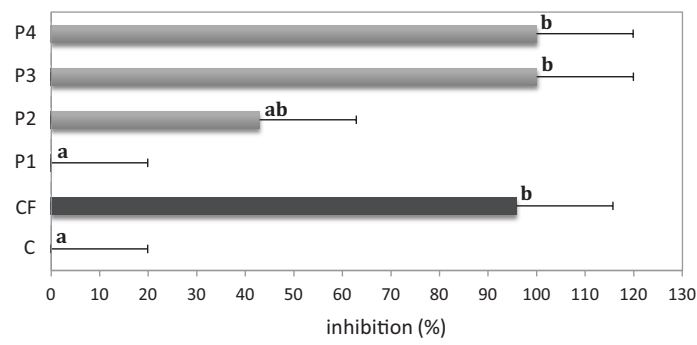

Ulocladium sp.

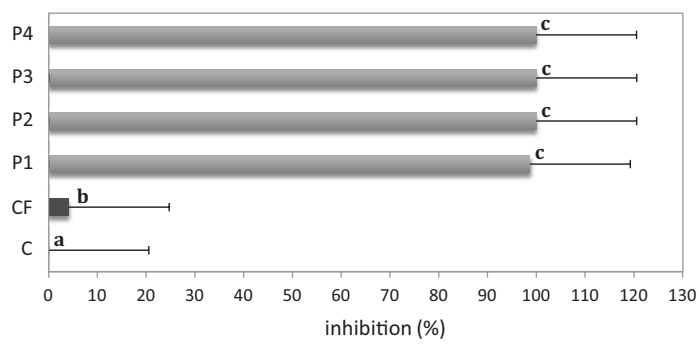

Trichoderma reesei

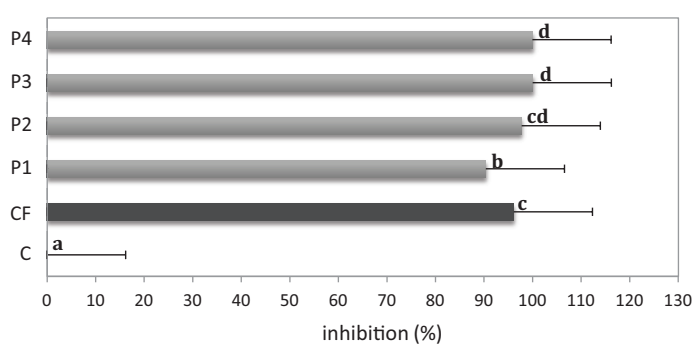

Penicillium expansum

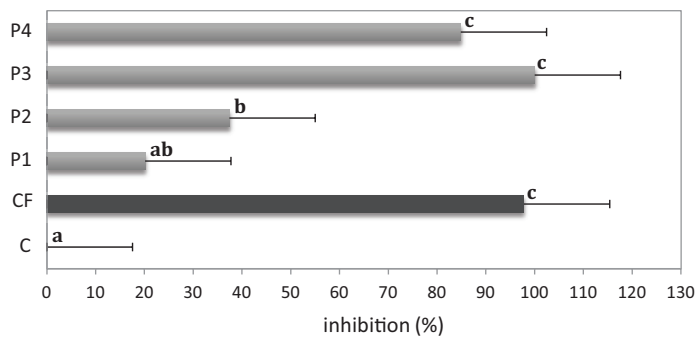

Botrytis cinerea

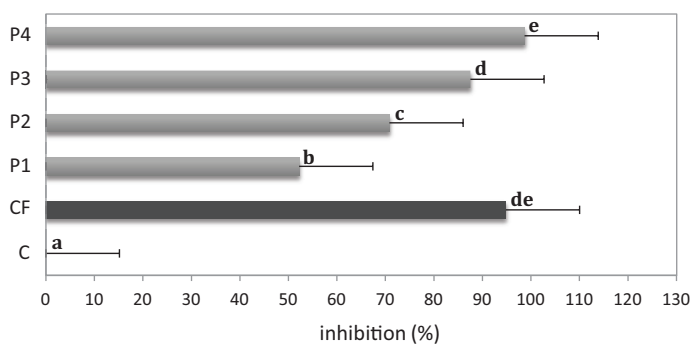

Figure 4. Percentages of inhibition by EEP-3. C: control without fungicide. CF: chemical fungicide. P1, 0.5\% EPP-3; P2, $1 \%$ EPP-3; P3, 2.5\% EPP-3 and P4, 5\% EPP-3. Each bar represents the average of 3 independent plates, plus the standard deviation. The letters on the bars indicate significant differences $(\mathrm{P} \leq 0.05)$.

geographical features and local climatic (Seidel et al., 2008) and seasonal effects (Valencia et al., 2012). The exogenous factors are related to the extraction by the beekeeper and include the harvest season (Simões-Ambrosio et al., 2010), the method used (Sales et al., 2006), the type of extractant (Tosi et al., 1996; Longhini et al., 2007) and the extractant concentration (Dos Santos et al., 2003).

EEP-3 is produced by an association of beekeepers in the region La Araucanía that has a reproducible protocol for preparing ethanol extracts of propolis each year. Over the last four years $(2007,2008$, 2009 and 2010), the EEP produced has had similar values of total polyphenols and total flavonoids (data not shown), indicating the importance of the association of beekeepers that have standardized methods (FIA, 2009).

The fungi used in this study are common causal agents of various agricultural diseases, spoilage, food contamination and mycotoxin production. New control agents are needed to manage the pathogenic fungi in plants $(A$. alternata, Fusarium sp., and Ulocladium sp.) and manage postharvest pathogenic fungi $(B$. cinerea and $P$. expansum). The results presented here showed that EEP-3 possesses in vitro antifungal activities against a broad spectrum 
of plant pathogenic fungi and could be used as a potential antifungal agent for the control of fungal plant diseases. Furthermore, EEP-3 also presented an antifungal activity against the biological control fungus (T. reesei). Garedew et al. (2004) indicate that the minimum concentration of propolis that caused the growth inhibition of filamentous fungi was between $0.5 \%$ and $2.5 \%$, which is similar to that obtained in this study for the fungi tested. Basim et al. (2006) examined the antimicrobial activity of extracts of pollen and propolis and found that the antimicrobial activity of EEP was greater than the pollen extract, which is a result that was attributable to the presence of phenolic compounds. Quiroga et al. (2006) assayed the use of Argentinean propolis against several species of xylophagous and phytopathogenic fungi and, similar to Hegazi and Abd El Hady (2002), successfully demonstrated the inhibition of the fungal pathogens by the propolis samples.

Another important aspect to consider is that, as noted by Bankova (2005b), the function of propolis is to protect the bees against infections that occur in the hive. Therefore, independent of whether the protective chemical variability is maintained, the inhibitory activity of propolis is associated with the synergy of its components, consistent with Garedew et al. (2004), Meneses et al. (2009) and Petrova et al. (2010), and it has not been shown experimentally that only a single component has greater activity than the total extract (Agüero et al., 2010). However, Treutter (2006) discussed the significance of flavonoids in the protection and resistance of plants to phytopathogens, particularly fungi, and phenolics and flavonoids are proposed to be the main antimicrobial components of propolis. Some flavonoids with strong antimicrobial activities have been identified in propolis collected from various regions. Pinocembrin, pinobanksin, chrysin and galangin in Chinese propolis demonstrated strong antifungal activities against P. italicum (Yang et al., 2011), whereas the main antimicrobial compound was found to be galangin in Bulgarian propolis (Campana et al., 2009). In Sonoran propolis (Mexico) pinocembrin, pinobanksin 3-acetate, chrysin, CAPE, acacetin and galangin were present in propolis samples collected four seasons (Valencia et al., 2012). We identified caffeic acid, myricetin, quercetin, kaempferol, apigenin, pinocembrin, galangin, CAPE and rutin in EEP-3 (Table 2) and suggest that pinocembrin and galangin could be responsible for the antifungal activity.

In summary, our results indicate that the ethanolic extract of Chilean propolis has the capacity to inhibit certain important economical agricultural fungi in vitro. The results obtained in this study are promising and support the importance of further in vivo investigations into the antifungal capacity of propolis from the region of La Araucanía. The inclusion of such natural products as propolis extract in crop protection strategies will help to maintain the balance of agroecosystems and the safety of the harvested products.

\section{Acknowledgments}

This study was supported by a grant from Dirección de Investigación y Desarrollo, Universidad de La Frontera DI-10-0023 project and CONICYT (FONDEF D05I-10021), Chile. 


\title{
Resumen
}

\begin{abstract}
M. Curifuta, J. Vidal, J. Sánchez, A. Contreras, L.A. Salazar y M. Alvear. 2012. Evaluación de la actividad antifúngica in vitro de un extracto comercial de propóleos Chileno contra seis hongos de interés agrícola. Cien. Inv. Agr. 39(2): 347-359. El propóleo ha sido utilizado por el hombre desde hace milenios por sus propiedades antimicrobianas y farmacéutica. Sin embargo, su uso como un agente antifúngico agrícola sólo recientemente ha sido evaluado. Con el objetivo de estudiar su capacidad antifúngica se caracterizaron químicamente seis extractos etanólicos (EEP1-EEP6), comercializados en la Región de La Araucanía. Se evaluó el contenido de polifenoles y flavonoides totales presentes en los EEP, estos presentaron concentraciones de polifenoles totales en un rango de 7,8 a $42,3 \mathrm{mg} \mathrm{mL}^{-1}$ equivalentes de la mezcla pinocembrina: galangina 2:1, y de flavonoides totales en un rango que varió entre 4,0 y $19,7 \mathrm{mg} \mathrm{mL}^{-1}$ equivalentes de quercetina. Análisis por cromatografía líquida de alta resolución (HPLC) permitió la identificación del ácido cafeico, miricetina, quercetina, kaempferol, apigenina, pinocembrina, galangina, éster del ácido cafeico (CAPE) y rutina. Se seleccionó el EEP-3, pues presentó las mayores concentraciones de polifenoles y flavonoides totales 42,3 y 19,7 mg $\mathrm{mL}^{-1}$, respectivamente. El efecto antifúngico de cuatro diferentes concentraciones $(0,5 ; 1,0$; 2,5 y 5,0\%) del EEP-3 sobre los hongos Alternaria alternata, Fusarium sp., Ulocladium sp., Botrytis cinerea, Penicillium expansum y Trichoderma reesei, fue evaluado in vitro mediante el método de dilución en agar. Se presentaron diferencias significativas entre las concentraciones de extracto ensayadas. Los resultados indican que el EEP-3 inhibió el crecimiento micelial en los seis hongos evaluados.
\end{abstract}

Palabras clave: Alternaria alternata, antifúngico, Botrytis cinerea, flavonoides, Fusarium sp., Penicillium expansum, polifenoles, propóleos.

\section{References}

Agüero, M., M. González, B. Lima, L. Svetaz, M. Sánchez, S. Zacchino, G. Egly Feresin, G. Schmeda-Hirschmann, J. Palermo, D. Wunderlin, and A. Tapia. 2010. Argentinean propolis from Zuccagnia punctata Cav. (Caesalpinieae) Exudates: Phytochemical Characterization and Antifungal Activity. Journal Agricultural Food Chemistry 58: 194-201.

Bankova, V. 2005a. Chemical diversity of propolis and the problem of standardization. Journal of Ethnopharmacology 100:114-117.

Bankova, V. 2005b. Recent trends and important developments in propolis research. Evidence-based Complementary and Alternative Medicine 2:29-32.

Basim, E., H. Basim, and M. Özcan. 2006. Antibacterial activities of Turkish pollen and propolis extracts against plant bacterial pathogens. Journal of Food Engineering 77: 992-996.

Bedascarrasbure, E., L. Maldonado, A. Alvarez, and E. Rodríguez. 2004. Contenido de Fenoles y Fla- vonoides del Propóleos Argentino. Acta Farmacológica Bonaerense 23: 369-72.

Bedascarrasbure, E., L., Maldonado, W., Fierro, and A., Alvarez. 2006. Propóleos. Caracterización y normalización de propóleos argentinos. Revisión y actualización de composición y propiedades. Ediciones Magna. Buenos Aires, Argentina. 218 pp.

Campana, R., V., Patrone, I.T., Franzini, G. Diamantini, E. Vittoria, and W. Baffone. 2009. Antimicrobial activity of two propolis samples against human Campylobacter jejuni. Journal of Medical Food 12: 1050-1056.

Castagna, A., A. Pinto, N. Mazzini, M. Matiuzzi, M. Sá, and L. Ribeiro. 2004. Alcoholic propolis extract: antimicrobial activity. Ciencia Rural 34: 159-163.

Castro, M., J. Cury, P. Rosalen, S. Alencar, M. Ikegaki, S. Duarte, and H. Koo. 2007. Própolis do sudeste e nordeste do Brasil: influência da sazonalidade na atividade antibacteriana e composição fenólica. Química Nova 30: 1512-1516. 
Chaillou, L.L., and M.A. Nazareno. 2009. Chemical variability in propolis from Santiago del Estero, Argentina, related to the arboreal environment as the sources of resins. Journal of the Science of Food and Agriculture 89: 978-983.

Dos Santos, C., F. Arcenio, E. Carvalho, E. Lúcio, G. Araújo, L.Teixeira, N. Sharapin, and L. Rocha. 2003. Otimização do processo de extração de própolis através da verificação da atividade Antimicrobiana. Revista Brasileira de Farmacognosia 13: 71-74.

ElShafei, G., M.M. El-Said, H. Attia, and T.G.M. Mohammed. 2010. Environmentally friendly pesticides: Essential oil-based w/o/w multiple emulsions for anti-fungal formulations. Industrial Crops and Products 31: 99-106.

Falcão, S.I., M. Vilas-Boas, L.M. Estevinho, C. Barros, M.R. Domingues, and S.M. Cardoso. 2010. Phenolic characterization of Northeast Portuguese propolis: usual and unusual compounds. Analytical Bioanalysis Chemistry 396: 887-897.

FIA. 2009. Resultados y lecciones en desarrollo de productos a base de propóleos: Proyecto de innovación en la IX Región de La Araucanía: Pecuario/Apicultura. Fundación para la Innovación Agraria. Temuco, Chile. 58 pp.

Garedew, A., E. Schmolza, I. Lamprecht. 2004. Microbiological and calorimetric investigations on the antimicrobial actions of different propolis extracts: an in vitro approach. Thermochimica Acta 422: 115-124.

Ghaly M.F., S.M. Ezzat, and M.M. Sarhan. 1998. Use of propolis and ultragriseofulvin to inhibit aflatoxigenic fungi. Folia Microbiologica 43: 156-160.

Giovanelli, L. 2008. Evaluation of an ethanolic extract of propolis as a potential pre- and postharvest fungicide for 'Fuerte' avocado (Persea americana Mill.) Fruits and Orchards. Thesis of Master of Science to the University of the Witwatersrand. Johannesburg, South Africa. $127 \mathrm{pp}$.

Gómez-Caravaca, A.M., M. Gómez-Romero, D. Arráez-Román, A. Segura-Carretero, and A. Fernández-Gutiérrez. 2006. Advances in the analysis of phenolic compounds in products derived from bees. Journal of Pharmaceutical and
Biomedical Analysis 41: 1220-1234.

Hegazi, A.G., and F.K. Abd El Hady. 2002. Egyptian Propolis: 3. Antioxidant, Antimicrobial Activities and Chemical Composition of Propolis from Reclaimed Lands. Z Naturforsch [C] 57:395-402.

Herrera, C., M. Alvear, L. Barrientos, G. Montenegro, and L. Salazar. 2010. The antifungal effect of six commercial extracts of Chilean propolis on Candida spp. Ciencia e Investigación Agraria 37: 75-84.

Hroboňová, K., J. Lehotay, and J. Čižmárik. 2008. Determination of Some Phenolic Acids in Propolis by an HPLC Method. Journal of Liquid Chromatography \& Related Technologies 31: 12131226.

Kalogeropoulos, N., S.J. Konteles, E. Troullidou, I. Mourtzinos, and V.T. Karathanos. 2009. Chemical composition, antioxidant activity and antimicrobial properties of propolis extracts from Greece and Cyprus. Food Chemistry 116: 452-461

Latorre, B. A., C. Lillo, and M. E. Rioja. 2001. Eficacia de los tratamientos fungicidas para el control de Botrytis cinerea de la vid en función de la época de aplicación. Ciencia e Investigación Agraria 28: 61-66.

Little, H.T., and F.S. Hills. 1976. Métodos estadísticos para la investigación en la agricultura. Editorial Trillas S.A. México. 271 pp.

Longhini, R., S. Raksa, A. Oliveira, T. Svidzinski, and S. Franco. 2007. Recopilación de extractos de propóleos en diferentes condiciones y la evaluación de su actividad antifúngica. Revista Brasileira de Farmacognosia 17: 388-395.

Lotti, C., M. Campo Fernández, A. Lisa Piccinelli, O. Cuesta-Rubio, I. Márquez Hernández, and L. Rastrelli. 2010. Chemical Constituents of Red Mexican Propolis. Journal of Agricultural and Food Chemistry 58: 2209-2213.

Melliou, E., E. Stratis, and I. Chinou. 2007. Volatile constituents of propolis from various regions of Greece - Antimicrobial activity. Food Chemistry 103: 375-380.

Meneses, E., D.L. Durango, and C.M. García. 2009. Antifungal activity against postharvest fungi by extracts from colombian propolis. Química Nova 32: 2011-2017. 
Ordoñez, R.M., I.C. Zampini, M.I., Nieva Moreno and M.I. Isla. 2011. Potential application of Northern Argentine propolis to control some phytopathogenic bacteria. Microbiological Research 166: 578-584.

Özcan, M., A. Ünver, D.A. Ceylan, and R. Yetişir. 2004. Inhibitory effect of pollen and propolis extracts. Nahrung/Food 48:188-194.

Özdemir, A.E, E.E. Çandir, M. Kaplankiran, E.M. Soylu, N. Şahinler, and A. Gül. 2010. The effects of ethanol-dissolved propolis on the storage of grapefruit cv. Star Ruby. Turkish Journal of Agriculture and Forestry 34:155-162.

Peña, R. 2008. Estandarización en propóleos: antecedentes químicos y biológicos. Ciencia e Investigación Agraria 35: 17-26.

Petrova, A., M. Popova, C. Kuzmanova, I. Tsvetkova, H. Naydenski, E. Muli, and V. Bankova. 2010. New biologically active compounds from Kenyan propolis. Fitoterapia 81: 509-514.

Popova, M., V. Bankova, S. Bogdanov, I. Tsvetkova, C. Naydenski, G. Marcazzan, and A. Sabatini. 2007. Chemical characteristics of poplar type propolis of different geographic origin. Apidologie 38:306.

Popova, M., I. Chinou, I. Marekov, and V. Bankova. 2009. Terpenes with antimicrobial activity from Cretan propolis. Phytochemistry 70: 12621271.

Popova, M., S. Silici, O. Kaftanoglu, and V. Bankova. 2005. Antibacterial activity of Turkish propolis and its qualitative and quantitative chemical composition. Phytomedicine 12: 221-228.

Quintero-Mora, M., A. Londono-Orozco, F. Hernández-Hernández, P. Manzano-Gayosso, R. LópezMartínez, C.I. Soto-Zarate, L. Carrillo-Miranda, G. Penieres-Carrillo, C.G. García-Tovar, and T.A. Cruz-Sánchez. 2008. Efecto de extractos de propóleos mexicanos de Apis mellifera sobre el crecimiento in vitro de Candida albicans. Revista Iberoamericana de Micología 25: 22-26.

Quiroga, E.N., D.A. Sampietro, J.R. Sobero'N, M.A. Sgariglia, and M.A. Vattuone. 2006. Propolis from the northwest of Argentina as a source of antifungal principles. Journal of Applied Microbiology 101: 103-110.
Russo A., V. Cardile, F. Sánchez, N. Troncoso, A. Vanella, and J.A. Garbarino. 2004. Chilean propolis: antioxidant activity and antiproliferative action in human tumor cell lines. Life Sciences 76 : 545-558.

Saavedra, N., L. Barrientos, C. Herrera, M. Alvear, G. Montenegro, and L. Salazar. 2011. Effect of Chilean propolis on cariogenic bacteria Lactobacillus fermentum. Ciencia e Investigación Agraria $38: 117-125$.

Salamanca, G., I. Correa, and J. Principal. 2007. Perfil de flavonoides e índices de oxidación de algunos propóleos colombianos. Zootecnia Tropical 25: 95-102.

Sales, A.; A. Álvarez, M. Rodríguez Areal, L. Maldonado, P. Marchisio, M. Rodríguez, and E. Bedascarrasbure, 2006. The effect of different propolis harvest methods on its lead contents determined by ET AAS and UV-VIS. Journal of Hazardous Materials 137: 1352-1356.

Sambrook J., and D.W. Russell. 2001. Molecular Cloning: A Laboratory Manual, 3rd ed. Cold Spring Harbor Laboratory Press. Harbour, NewYork.

Saiki, R.K, D.H. Gelfand, S. Stoffel, S.J. Scharf, R. Higuchi, G.T. Horn, K.B. Mullis, and H.A. Erlich. 1988. Primer-directed enzymatic amplification of DNA with a thermostable DNA polymerase. Science 239: 487-491.

Seidel, V., E. Peyfoon, D.G. Watson, and J. Fearnley. 2008. Comparative Study of the Antibacterial Activity of Propolis from Different Geographical and Climatic Zones. Phytotherapy Research 22: 1256-1263.

Simões-Ambrosio, L., L. Gregório, J. Sousa, A. Figueiredo, A. Azzolini, J. Bastos, and Y. Lucisano-Valima. 2010. The role of seasonality on the inhibitory effect of Brazilian green propolis on the oxidative metabolism of neutrophils. Fitoterapia 81: 1102-1108.

Singleton, V. L., R. Orthofer, and R.M. LamuelaRavento's. 1999. Analysis of total phenols and other oxidation substrates and antioxidants by means of Folin-Ciocalteau reagent. Methods of Enzymology 299: 152-178.

Strange, R. N., and P. R. Scott. 2005. Plant Disease: 
A threat to global food security. Annual Review of Phytopathology 43: 83-116.

Tolosa, L., and E. Cañizares. 2002. Obtención, caracterización y evaluación de la actividad antimicrobiana de extractos de propóleos de Campeche. Ars Pharmaceutica 43: 187-204.

Tosi, B., A. Donini, C. Romagnoli, and A. Bruni. 1996. Antimicrobial Activity of Some Commercial Extracts of Propolis Prepared with Different Solvents. Phytotherapy Research 10: 335-336.

Treutter, D. 2006. Significance of flavonoids in plant resistance: review. Environmental Chemistry Letters 4: 147-157.

Valencia, D., E. Alday, R. Robles-Zepeda, A. GaribayEscobar, J.C. Galvez-Ruiz, M. Salas-Reyes, M. Jiménez-Estrada, E. Velázquez-Contreras, J. Hernández, and C. Velázquez. 2012. Seasonal effect on chemical composition and biological activities on Sonoran propolis. Food Chemistry 131: 645-651.

Vidal, J., A., Lillo, P., Ávila, G., Catalán, and M., Alvear. 2009. Evaluación de extractos de propóleos sobre aislados fúngicos obtenidos de suelo, de frutos y hortalizas de la Región de La Araucanía. Anales XV Congreso Latinoamericano de Fitopatología. Santiago, Chile. p. 332.
White, T.J, T. Bruns, S. Lee, and J.W. Taylor. 1990. Amplification and direct sequencing of fungal ribosomal RNA genes for phylogenetics, in PCR Protocols: A Guide to Methods and Applications. In: M.A. Innis, D.H. Gelfand, J.J. Sninsky, and T. J. White (eds.). Academic Press, NewYork. p. 315-322.

Wightwick, A., R. Walters, G., Allinson, S., Reichman, and N. Menzies. 2010. Environmental Risks of Fungicides Used in Horticultural Production Systems. Chapter 14. P. 273-304. Fungicides. Edited by Odile Carisse. InTech. $538 \mathrm{pp}$.

Yang, S.Z., L.T., Peng, X.J., Su, F., Chen, Y.J., Cheng, G. Fan, and S.Y., Pan. 2011. Bioassayguided isolation and identification of antifungal components from propolis against Penicillium italicum. Food Chemistry 127: 210-215.

Zhao, M., J.Y. Zhou, Z.D. Li, W.W., Song, Y.J. Tan, and T. Hong. 2009. Boty-II, a novel LTR retrotransposon in Botrytis cinerea B05.10 revealed by genomic sequence. Electronic Journal of Biotechnology 12:2-3. 
